Jernej Kovač

ORCID:https://orcid.org/0000-0001-8576-1498

Marija Javornik Krečič

ORCID: https://orcid.org/0000-0002-9122-2025

University of Maribor, Slovenia

\title{
Association \\ between one's attachment to parents and subsequent attachment to a partner
}

\begin{abstract}
The primary purpose of this study was to explore the association between individuals' attachments to their mothers and fathers, and their subsequent attachments to partners, based on research conducted in Slovenia. Participants in the empirical study were antenuptial couples who attended the premarital counselling course organized by and offered through the Franciscan Family Institute in Ljubljana, Slovenia. In order to explore more fully the concept of attachment, the authors of the study focused on the following dimensions: trust, communication and estrangement. The results of the study showed greater similarities in the three identified dimensions to the way in which both women and men experience attachment to their mothers and partners, while there were marked differences in the subjects' experience of attachment to their fathers.
\end{abstract}

\section{Keywords}

Attachment, child, partner, father, mother. 


\section{Introduction}

The last two decades have seen an increase in the number of professional and scientific studies that focus on concepts of attachment. Much of the research explores this question: During what developmental stage is the attachment most strongly imprinted upon the human psyche? Numerous studies ${ }^{1}$ prove that the patterns of attachment are most strongly imprinted during the earliest stage of a human life. This stage lays the foundation by which an individual is primed for attachment to other important people later on in life. ${ }^{2}$ Findings that established connections between attachment patterns in relationships between parents and children ${ }^{3}$ and subsequent patterns of attachment to partners, are especially interesting.

At the time that this project was launched, there had not yet been a systematic scientific study in Slovenia that thoroughly examined attachment patterns between individuals and their primary families, and their subsequent attachment to partners. The findings of this study will help to fill the gap in research-based information for that aspect of the data on attachment.

This document consists of two sections: one foocusing on theoretical concerns and the other focusing on empirical processes and data. In the first section - the theoretical part - we describe the concept of attachment in some detail. This is followed by an outline of communicative interactions between a mother and a child in their earliest period of life, a time known as the "symbiotic period." Later, we present information about the three attachment styles (safe, avoiding, ambivalent) that can be established in the mother-child relationship. We close the theoretical section with a short comment on the impact of a child's early attachment to a parent (or parents) on his/her later attachment in adulthood, focusing on partner relationships. In the second section - the empirical section we define the contents and the methods of our research, and follow that with

${ }^{1}$ J. Bowlby, Attachment. Attachment and loss, New York 1969; C. Gostečnik, Poskusiva znova, Ljubljana 2001; C. Gostečnik, So res vsega krivi starši?, Ljubljana 2014; T. Erzar, L.K. Kompan Erzar, Teorija navezanosti, Celje 2011; L. K. Kompan Erzar, Skrita moč družine, Ljubljana 2003; L.K. Kompan Erzar, Ljubezen umije spomin, Ljubljana 2006; D. Stern, The interpersonal world of the infant, Cambridge 1985.

2 C. Gostečnik, So res vsega krivi starši? Ljubljana 2014.

3 C. Gostečnik, Poskusiva znova, Ljubljana 2001; M. Mikulincer, P.R. Shaver, Attachment in adulhood: Structure, dynamics and change, New York 2010. 
a presentation of the results and our interpretations. This paper ends with our final conclusions and guidelines for further development and research practice.

\section{Definitions of the concept of attachment}

John Bowlby, renowned pioneer researcher in the concept of attachment ${ }^{4}$, defines attachment as a person's ability to establish and maintain connections to people; connections that can have an impact upon his/her existence ${ }^{5}$. By this definition, a child craves his/her mother's presence since birth, as this attachment makes him/her feel safe. ${ }^{6}$ When a child becomes confident that the mother will be emotionally available when needed, that child can move away from his/her parents knowing that he/she can return at any time and maintain the closeness. Thus, feelings of safety remain present and significant to the child. One could propose that attachment is a specific way of communicating with the reality of the interpersonal world; a communication pattern that is established in early childhood years when the child learns how to call his/her parents and maintain contact with them. ${ }^{7}$

Attachment denotes the basic form of a definition of the self as a structure that is built into the child-mother-father relationship. ${ }^{8}$ In this primary relationship, all important experiences from early childhood are imprinted upon the child's psyche - that is, both the child's needs and the parents' responses to the child's needs, as well as their feelings in regards to the needs, become imprinted. These imprints are the foundation for the building of the child's psychological world view. ${ }^{9}$ In this period of early brain development, the number of neurons increases markedly; $90 \%$ of all neural connections are created during this time. ${ }^{10}$

Basic elements of attachment are established in the earliest period of life, specifically during the child's first three years. Systems of attachment are formed

${ }^{4} \mathrm{M}$. Kuhar, K. Jeznik, Effects of group discussion attachment styles and facilitation on the quality of deliberation. Društvena istraživanja, Zagreb 2018, pp. 281-303.

J. Bowlby, Attachment. Attachment and loss, New York 1969.

${ }^{6}$ D. Stern, The present moment in psychotherapy and evryday life, New York 2004.

${ }^{7}$ L. K. Kompan Erzar, Skrita moč družine, Ljubljana 2003.

${ }^{8}$ T. Erzar, L. K. Kompan Erzar, Teorija navezanosti, Celje2011.

9 C. Gostečnik, Poskusiva znova, Ljubljana 2001.

${ }^{10}$ L. K. Kompan Erzar, Skrita moč družine, Ljubljana 2003. 
in four stages which differ in length. Stages depend on the empathy and sensitivity of the person the child forms an attachment to. Developmental phases of attachment are described by Bowlby ${ }^{11}$ as follows:

1. Orientation and signals, with a limited distinction between people who are present. During this phase, the child is already acting/responding in certain/particular ways towards people, but can (? only) differentiate between them based on olfactory and auditory stimuli. (This phase lasts from birth to 8-12 weeks.).

2. Orientation and signals directed towards one, or several, particular/ specific persons.. In this phase, the child behaves in a friendly manner towards people (in general), but responds with greater intensity towards the mother. The child can already distinguish between the mother, the father and other people, and typically exhibits a differentiated response towards the mother, based on sound. The responsiveness can be noticed especially after week 12 , when the mother's voice becomes the most important stimulus for the child. (This phase lasts approximately 6 months for children who are growing up at home.).

3. Keeping an important person close with the help of movements and other signals. In this phase, the child reacts differently to his/her mother's comings and goings; when she is leaving, he/she follows her with his/her eyes whereas, when the mother is approaching, he/she greets her and uses her as a safe base/reference for his/her exploration - which means that the child visually explores the surroundings and always returns to his/her mother. Friendly reactions to other people slowly diminish, and the child becomes more wary of/ cautious with strangers. During this phase, he/she develops behaviour that serves as a foundation for directing behaviour with a particular purpose or goal (goalcorrected basis). Attachment to the mother is already (clearly) noticeable in this period. (This phase typically starts between 6 to 12 months, but in some cases, it is postponed to a period after the first year and may last into the third year.).

4. Forming partnerships, with the possibility of directing behaviour based on purpose or goal (goal-corrected partnerships). This is the period when the child slowly recognizes his/her mother's intentions and autonomy, and he/she slowly (gradually perceives OR starts to per-

${ }^{11}$ L. K. Kompan Erzar, Ljubezen umije spomin, Ljubljana 2006. 
ceive) perceives his/her mother as a person who has her own agenda the child starts to understand that the mother has her own feelings and motives. This period involves developing relationships and partnerships while also establishing cooperation styles. (This phase starts at around 3 years of age.).

Attachment styles starts to form and build its foundations very early on, as the basic mechanisms of responding to and perceiving the world are innate - they are present and active in children since birth ${ }^{12}$. In this earliest period of mutual cooperation, a child is most perceptive of, and responsive to, all stimuli from his/her mother ${ }^{13}$. Thus, the child forms a first connection, and its first symbiotic association and communication that materializes in the emotional dimension ${ }^{14}$ and in body sensations. ${ }^{15}$

\section{Communication between the child and the mother}

Primary communication between a mother and her child is based on the mechanism of projective-introjective identification. ${ }^{16}$ The concept of projective-introjective identification denotes unconscious communication, chiefly based upon the projection of the child, who transfers individual internal psychological states onto his/her mother (e.g. distress, sadness). ${ }^{17}$ The mother identifies with the child's psychological states and consequently can respond to them. ${ }^{18}$ Dyadic emotional processes (regulation of emotions) between the child and the mother

${ }^{12}$ C. Gostečnik, Poskusiva znova, Ljubljana 2001.

${ }^{13}$ C. Izard, On the Development of Emotions and Emotion-Cognitive Relationships in Infancy. The Development of Affect, New York 1978; D. Stern, The present moment in psychotherapy and everyday life, New York 2004; S. Mitchell, Relational concepts in Psychoanalysis, Harvard 1988.

${ }^{14}$ S. Blatt, R. Blass, Relatedness and self-definition: A dialectic model of Personality Development, New Jersey 1996.

${ }^{15}$ B. van der Kolk, Treating Trauma Survivors with PTSD, Washington 2002.

${ }^{16}$ B. Rotschild, Help for the helper: The psychophysiology of compassion fatigue and vicarious trauma, New York 2006; C. Gostečnik, Poskusiva znova, Ljubljana 2001; A. Schore, Affect Disregulation and disorder of the Self, New York 2003.

${ }^{17}$ C. Gostečnik, R. Cvetek, T. Pate, Saša Poljak Lukek, B. Simonič, T. Valenta, T. Repič Slavič, The impact to fearly aggression on late development, "The Person and the Challenges" (2019), pp. 169-192.

${ }^{18}$ A. Schore, Affect Disregulation and Disorder of the Self, New York 2003. 
include tuning, empathy, affective resonance, eye contact, vocal rhythms, and mutual shared satisfaction. ${ }^{19}$ These processes take place in the right hemisphere of the brain and are connected to positive affective states. ${ }^{20}$ Based on unconscious communication with his/her mother, the child can form a basic idea about him/ her-self. ${ }^{21}$ Kompan-Erzar ${ }^{22}$ claims that, for the child to form the idea about him/her-self in the earliest period of life, it is crucial that the mother is capable of detecting and being in touch with her own feelings, and that she is also able to separate them from the feelings which her child awakens in her (projects onto her). In that case, her response to the child and his/her psychophysical state can be spontaneous and directed towards him/her.

\section{Attachment styles}

Mary Ainsworth put Bowlby's theory into practice and confirmed it with empirical data. She launched numerous research studies delving into the attachment between parents and children. In her research, Ainsworth focused mostly on the early dyadic relationship between mother and child. ${ }^{23}$ Several one-year-olds and their parents participated in one of her studies. She researched different forms of interaction between mothers and children, especially each mother's responses to the child's needs, such as: feeding, crying, pampering, caressing, eye contact, laughter, and communication via facial expressions. Each mother and child were observed for 72 hours. The time was divided into 18 sessions of 4 hours each. The one-year-olds were observed together with their mothers in laboratories, where they were exposed to a series of procedures called "foreign situations". Each mother and child were taken into a room filled with toys, where they were welcomed by a research assistant who then invited the child to start playing with the toys. Ainsworth then observed the child's behaviour as the mother left the room, three times for three-minute intervals. During two

${ }^{19}$ B. Simonič, Empathic parenting and child development, "The Person and the Challenges" (2015), pp. 109-121.

${ }^{20}$ R. Cvetek, Predelava disfunkcionalno shranjenih stresnih izkušenj ter metoda desenzitacije in ponovne predelave $z$ očesnim gibanjem. Dissertation, Ljubljana 2004.

${ }^{21}$ J. Bradshaw, The Family: A revolutionary way of selfdiscovery, Florida 1988.

${ }^{22}$ L. K. Kompan Erzar, Skrita moč družine, Ljubljana 2003.

${ }^{23}$ C. Gostečnik, Poskusiva znova, Ljubljana 2001. 
of these intervals, the research assistant stayed in the room. In the third interval the child was left alone in the room. Based on this study, outlines and definitions of three attachment styles were formed:

1. Safe attachment: For two-thirds of the children, a distinct flexibility was characteristic: The children were capable of playing with toys on their own in the room. When their mothers left, they protested and cried - but after a short interval of rejection ( 3 minutes), the children were happy to accept her absence and were not difficult to console.

2. Avoidant attachment: Around 20 to 25 percent of the children gave the impression that they were independent, because they acted as though they did not even notice the presence of their mothers. These children explored the new environment and, not needing their mother to be "the safe center," they did not turn to her to make sure that she was present. They also did not react to the mother leaving the room or returning to it. While superficially the children exhibited apathic behaviour, a concurrent measure of their vital signs (heart rate, temperature etc.) showed serial distress that was not visually noticeable.

3. Anxiety-Ambivalent attachment: Around 10 percent of the children were found to be anxiously/ambivalently attached. With this form of attachment, the children were focused on their mothers the entire time and were not capable of playing on their own. The children were snuggling up to the mothers and appeared afraid to explore the room and/or play with toys. Once the mother left, the child became terribly frightened and upset, and often cried inconsolably. When the mother returned, the child sought contact but at the same time rejected her and her efforts to console them. ${ }^{24}$

${ }^{24}$ C. Gostečnik, Poskusiva znova, Ljubljana 2001. 


\section{Impact of early attachment of the child on later attachment in adulthood}

Some researchers ${ }^{25}$ came to the conclusion that particular forms of attachment in individuals created in early childhood, persist into adulthood.. In their study, Shaver and Hazande describe three forms of attachment in adulthood:

1. Safe attachment. Adults who experience safe attachment in chilhoos are satisfied in their close relationships and can easily get attached to others because they feel worthy of love and respect. They tend to trust others and believe that they can count on others whenever they need or want them. Such adults can also establish intimate relationships easily, and are not afraid that their partner will leave or reject them.

2. Anxious/ambivalent attachment. Adults with this style of attachment see others as reserved in forming attachments towards them; they are constantly upset and afraid that their partners do not love them. They also worry that the partner will leave them. As a result of that fear, they often limit their partner in the relationship and some are very jealous. People with this attachment style think and feel that other people do not respect them enough - or at least not as much as others should. They are also afraid of being rejected, and they fear that their love will not be reciprocated and/or fulfilled. At the same time, these adults are afraid of being close to and dependent upon someone else.

3. Avoidant attachment. Adults with this attachment style avoid intimate relationships and feel alone most of the time. They are uncomfortable when emotionally close to someone; they find it hard to relax with others and have numerous trust issues. They feel agitated if someone comes too close, and very often, their partners want to be in a more intimate relationship than they will allow emotional space for. It appears that such adults often settle for short-lived relationships, tend to be unfaithful, and have sexual intercourse without thinking of or involving emotions. ${ }^{26}$

${ }^{25}$ J. Bowlby, Attachment. Attachment and loss. Attachment, 2ed. New York 1982; B. Rothschild, The body remembers: The psychophysiology of trauma and trauma treatment. New York 2000; A. Schore, Affect Disregulation and disorder of the Self, New York 2003.

${ }^{26}$ C. Gostečnik, Poskusiva znova, Ljubljana 2001. 
According to Bowlby the basic assumptions/hypotheses of attachment theory in connection with intimate relationships later in life, have the following structure:

- Based on early relationship experiences, internal working models develop and define adult intimate relationships;

- Based on these created models, individuals will build a belief on whether or not they are worthy of love and can trust others to develop love and support for them;

- Based on the interpersonal interactions, an individual establishes relationships with others, especially with the people closest to him/her. ${ }^{27}$

Brajša-Žganec ${ }^{28}$ claim that effective communication of emotions in the child's early years can prevent emotional deprivation and dysfunctional emotion systems, foster the development of socio-emotional competence and prevent behavioral problems such as aggression, violence, and social withdrawal.

An extremely complex study of different styles of romantic attachment from Mickelson et al.1997, involving several thousands of male and female participants, offered some interesting conclusions. It showed that $59 \%$ of adults are safely attached, $11 \%$ are anxiously-ambivalent and $25 \%$ show/exhibit avoiding attachment. This matches the results that Ainsworth came to (recorded) more than two decades before. ${ }^{29}$. Belsky and Fearon $(2008)^{30}$ also came to similar conclusions; in their study, they determined that a damaging attachment in childhood leads to a lower quality in an adult partnership.

Following a detailed review of attachment-related literature in Slovenia, it was determined, in the theoretical section, that studies which would establish correlational connections between attachment to the mother, the father and partners are practically nonexistent. Thus, the empirical research presented on the following pages will fill that gap.

${ }^{27}$ J. Bowlby, Attachment. Attachment and loss, New York 1982.

28 A. Brajša Žganec, Emotional Life of the Family: Parental Meta-Emotions, Childrens' Temperament and Internalising and Externalising Problems, Društvena istraživanja, Zagreb 2014, pp. 25-45.

${ }^{29}$ C. Gostečnik, Poskusiva znova, Ljubljana 2001.

${ }^{30}$ J. Belsky, R. M. Fearon, Precursors of attachment security, in: J. Cassidy, P.R. Shaver (eds.), Handbook of attachment: Theory, research and clinical applications, 2008, pp. 295-316. 


\section{Method}

\subsection{Participants in the study}

The study is based on a non-random sample of 59 antenuptial couples, who attended an antenuptial course organized by the Franciscan Family Institute in Ljubljana, Slovenia.

The average age of the female participants was 25.13 years; the average age for male participants was 26.46 years. More than half of all the participants in the study $(51.8 \%)$ had earned a university degree and the rest (48.2\%) held high school degrees.

\subsection{Instruments and materials}

A questionnaire titled "Inventory of parent and peer attachment" ${ }^{31}$ was used in the study. The questionnaire includes 25 closed-type statements with a fivegrade scale, for the mother, the father, and the partner. The questionnaire uses the data gathered from its application to evaluate attachment. As defined in this study, attachment consists of the following dimensions: trust, communication, and estrangement.

The questionnaire shows good internal reliability, as the Cronbach alfa coefficient for the entire scale is 0.89 . Reliability was also ensured by providing the participants with clear and precise instructions for filling out the questionnaire.

\subsection{The research process}

The questionnaire was given to all participants following the antenuptial course. Antenuptial couples were informed in advance that their cooperation was voluntary and anonymous, and that all of the gathered data would be used solely for scientific-research purposes. Couples returned their answers to the questionnaire via postal mail.

${ }^{31}$ G. Armsden, M. Greenberg, The Inventory of Parentand Peer Attachment: Relationship to well-being in adolescence. Journal of Youth and Adolescence 1987, pp. 427-454. 


\subsection{Data processing}

Acquired data was statistically processed with the SPSS program (Statistical Package for Social Sciences). The Pearson correlation coefficient was used for calculating attachment in different dimensions (trust, communication, estrangement) and was interpreted as a measure of effect size $\mathrm{e}^{32}$ in accordance with criteria for small effect $\left(r=0.10\right.$ or $\left.r_{2}=0.01\right)$, medium effect $\left(r=0.30\right.$ or $\left.r_{2}=0.09\right)$ and large effect $(r=0.50$ or. $r 2=0.25)$.

\section{Results and interpretation}

The following tables outline the results of an analysis of the completed questionnaires. Data points are shown separately for male and female participants with regards to their attachment to mother, father, and partner for the following attachment dimensions: trust, communication, and estrangement.

Table 1. Pearson correlation coefficient $\left(r, r^{2}\right)$ of trust in men and women towards their mothers and partners/fathers and partners

\begin{tabular}{|c|c|c|}
\hline \multirow{2}{*}{ Correlation } & Trust & Trust \\
\cline { 2 - 3 } & Mother/partner & Father/partner \\
\cline { 2 - 3 } & $r(r 2)$ & $r(r 2)$ \\
\hline Women & $0.39(0.15)$ & $0.28(0.09)$ \\
\hline Men & $0.23(0.05)$ & $-0.25(0.06)$ \\
\hline
\end{tabular}

First, we shall focus on correlation direction, where three positive and one negative correlation coefficients can be seen.

The results show that women with higher levels of trust towards their mothers also have higher levels of trust towards their partners $(r=0.39)$. Similarly, their higher levels of trust towards their fathers is connected to higher levels of trust towards the partner $(\mathrm{r}=0.28)$. Both cases(results) show a medium impact of trust in the relationship between a woman and her parents (especially her mother) and her subsequent trust towards her partner ( $9 \%$ to $15 \%$ ).

32 J. Cohen, Statistical Power Analysis for the Behavioral Sciences (2nd Ed) LEA, 1988; A. Field, Discovering Statistics using IBM SPSS Statistics (4th Ed), London 2013. 
The situation is different for the men. If men's level of trust towards their mothers is high, the same applies for trust towards their partners $(r=0.23)$. However, the data shows that men who demonstrate higher levels of trust towards their fathers exhibit lower levels of trust towards their partners ( $r=-$ 0.25 ). For a man, the effect of having a trusting relationship with both parents on subsequent trust towards partners, is low (5\% to $6 \%$ ).

Table 2. Pearson correlation coefficient $\left(r, r^{2}\right)$ for communication of women/ men and their mothers and partners/fathers and partners.

\begin{tabular}{|c|c|c|}
\hline \multirow{2}{*}{ Correlation } & Communication & Communication \\
\cline { 2 - 3 } & Mother/partner & Father/partner \\
\cline { 2 - 3 } & $r(r 2)$ & $r(r 2)$ \\
\hline Women & $0.22(0.05)$ & $-0.09(0.01)$ \\
\hline Men & $-0.02(0.00)$ & $-0.17(0.03)$ \\
\hline
\end{tabular}

Table 2 shows that all correlation coefficients for the communication dimension are low (three negative and one positive coefficient).

Looking at the data, we can conclude that in the female sample there is no correlation in the relationship father/partner $(\mathrm{r}=-0.09)$, but there is a correlation in the relationship mother/partner $(\mathrm{r}=\mathrm{0.22})$ : the stronger a woman's communication with her mother, the stronger it is with her partner as well.

In the male sample, there is no correlation in the relationship mother/partner $(\mathrm{r}=-0.02)$, but there is a small negative correlation in the relationship father/ partner $(r=-0.17)$. It can be concluded that a man's higher quality of communication with his father means a lower quality of communication towards his partner, and vice versa. Communication with the father has a relatively small effect on communication with the partner (3\%), but it must not be disregarded, as it shows that the quality of communication of a man with his father is not a reliable predictor for effective communication with his partner. This means that the trend concerning men and women is reversed, as the communication of a woman with her mother is a reliable predictor for later effective communication with her partner. 
Table 3: Pearson correlation coefficient $\left(r, r^{2}\right)$ for estrangement of women and men from their mothers/partners and fathers/partners

\begin{tabular}{|c|c|c|}
\hline \multirow{2}{*}{ Correlation } & Estrangement & Estrangement \\
\cline { 2 - 3 } & Mother/partner & Father/partner \\
\cline { 2 - 3 } & $r(r 2)$ & $r(r 2)$ \\
\hline Women & $0.50(0.25)$ & $0.14(0.02)$ \\
\hline Men & $0.38(0.14)$ & $-0.14(0.02)$ \\
\hline
\end{tabular}

Table 3 shows three positive and one negative correlation.

In the female sample, there is an important positive correlation in the relationship mother/partner $(\mathrm{r}=0.50)$ and a low positive correlation for father/ partner $(r=0.14)$. Higher levels of estrangement from mothers and fathers also means higher estrangement from partners. The effect of an estranged relationship between a woman and her mother on subsequent estrangement from her partner is significantly higher (25\%) than the effect of an estranged relationship between a woman and her father (2\%).

In the male sample, the correlation in relationship between mother/partner is also positive $(r=0.38)$. The data shows that a man who experiences estrangement from his mother is likely to increase estrangement from his partner with a medium impact of the estranged relationship with his mother on his partner relationship (14\%). Perceiving estrangement in the father/partner relationships stands out (is significant/prominent) $(\mathrm{r}=-0.14)$. It appears that a male who perceives a higher level of estrangement from his father is also likely to experience a lower level of estrangement from his partner. Although the effect of the relationship with a male's father is low (2\%), it is nevertheless an important discovery that the estrangement of men from their fathers does not necessarily lead to estranged relationships with their partners (as is similarly demonstrated with the dimension of communication in Table 2). On the contrary, the more estranged the relationship is between a man and his father, the more it predicts that he is less likely to be estranged from his partner, and vice versa. 


\section{Conclusion}

The results show that both women and men experience attachment patterns to the mother and the partner which are more similar than to those of the father and the partner, in all the identified dimensions of attachment. It must be pointed out that - in the research findings from all of the identified dimensions of attachment (trust, communication, estrangement/alienation) - women perceived the attachment to the mother and to the partner in similar ways (specifically, women who report higher levels of trust and communication with, and/ or estrangement from their mothers experience higher levels of these dimensions towards their partners), while men, experience the opposite in relation to the father/partner (men's higher levels of trust, communication, and estrangement lead to lower levels of these dimensional forms towards partners).

Thus, it was confirmed that the mother was found to be (revealed as) the more influential person, in terms of affecting the dimensions of attachment between partners, for both women and men. It should, however, also be noted that the attachment style between a woman and her mother has a greater influence on the woman's later attachment to a partner. The most powerful associations of attachment between a mother, a woman, and her partner are in the following two dimensions: trust and estrangement. Trust plays an important role in partnering relationships, as it presents a basis for building high-quality partnerships grounded in honesty, desirability and compassion. Estrangement also factors significantly into partnerships, as it often becomes the basis and impetus for conflicts and/or violence - in both professional and personal relationship and in marital divorces.

In recognizing the data that the attachment of the child to his/her mother and not to his/her father is a predictor of attachment in adulthood, researchers are faced with a new and challenging question: Why is this?

Mothers are historically perceived as being more involved in the upbringing of children than fathers ${ }^{33}$; a more traditional relational model that can be seen in diverse societies even today. ${ }^{34}$ It is a fact that the care and raising of children tends to fall more into the female domain, a paradigm which can also be observed at the level of secondary socialization. For example, significantly greater numbers of women are professionally engaged in the field of education than

\footnotetext{
A. Puhar, Prvotno besedilo življenja. Studia Humanitatis, Ljubljana 2004.

${ }^{34}$ T. Erzar, L. K. Kompan Erzar, Teorija navezanosti, Celje 2011.
} 
men, focusing on the teaching and the development of intellectual and social/ motor skills in children.

Future studies of attachment should also focus on the medical (endocrinological) and neuropsychological scientific findings on attachment between mothers and children. Some research has shown that effects of the hormone oxytocin in mothers' bodies may play a critical role in motherhood. It is known that the hormone supports the birth process by stimulating mothers' (uterine) contractions during labour; later, the hormone oxytocin also provides physiological support for mothers who choose to breastfeed their infants and young children. Some studies have suggested that the effects of increased levels of oxytocin in the body may also be in part responsible for the attachment of mothers to their children. ${ }^{35}$

These finding show that it would be sensible to raise awareness with the wider society - especially with parents - about attachment and how it pertains to mothers and their children. This could then inspire productive discussions focusing on how the mother-child relationship can potentially influence an adult's subsequent attachment to his/her partner.

In addition, raising awareness could have a positive impact on the quality of other significant partnerships, resulting in fewer relational and professional conflicts, and thus, minimizing the potential for resulting violence.

We could reasonably conclude that developing attachment in childhood that is, forging healthy relationships within one's family of origin - is a predictor for socially responsible behaviour in adulthood. Therefore, it must be considered that the role of the mother is of key importance (a child's healthy and positive attachment to his/her mother predicts that the child stands a better chance of developing into a socially responsible adult and a healthy, contributing member of society). While the role of the father is also important, our study suggest that it is not quite as significant as the role of the mother in facilitating healthy and influential attachments.

${ }^{35}$ X. Xie, S. Mulej Bratec, G. Schmid, C. Meng, A. Doll, A. Wohlschager, K. Finke, H. Forstl, C. Zimmer, R. Pekrun, L. Schilbach, V. Riedl, C. Sorg, How do you make me feel better? Social cognitive emotion regulation and the default mode network, "Neuroimage« 134 (2016), pp. 270-280. 


\section{Bibliography}

Armsden G., Greenberg M.,The Inventory of Parent and Peer Attachment: Relationship to well-being in adolescence. Journal of Youth and Adolescence 16 (1987) 5, pp. 427-454.

Belsky J., Fearon R. M., Precursors of attachment security, in: J. Cassidy, P.R.Shaver (eds.), Handbook of attachment: Theory, research and clinical applications, 2008, pp. 295-316.

Blatt S., Blass R., Relatedness and self-definition: A dialectic model of Personality Development, New Jersey 1996: Lawrence Erlbaum Associates.

Bowlby J., Attachment. Attachment and loss, New York 1969: Basic Books.

Bowlby J., Attachment. Attachment and loss. Attachment, 2ed. New York 1982: Basic Books.

Bradshaw J., The Family: A revolutionary way of selfdiscovery, Florida 1988: Health communications inc.

Brajša Žganec A., Emotional Life of the Family: Parental Meta-Emotions, Children's Temperament and Internalising and Externalising Problems, »Društvena istraživanja " 23 (2014) 1, pp. 25-45.

Cohen J., Statistical Power Analysis for the Behavioral Sciences (2nd Ed) LEA, 1988.

Cvetek R., Predelava disfunkcionalno shranjenih stresnih izkušenj ter metoda desenzitacije in ponovne predelave z očesnim gibanjem, Dissertation, University of Ljubljana, 2004.

Erzar T., Kompan Erzar L.K., Teorija navezanosti, Celje 2011: Celjska Mohorjeva družba.

Field A., Discovering Statistics using IBM SPSS Statistics (4th Ed), London 2013, SAGE.

Gostečnik C., Poskusiva znova, Ljubljana 2001: Brat Frančišek in Frančiškanski družinski inštitut.

Gostečnik C., So res vsega krivi starši?, Ljubljana 2014: Brat Frančišek in Frančiškanski družinski inštitut.

Gostečnik C., Cvetek R., Pate T., Poljak Lukek S., Simonič B., Valenta T., Repič Slavič T., The impact of early aggression on late development, "The Person and the Challenges" 9 (2019) 2, pp. 169-192.

Izard C., On the Development of Emotions and Emotion-Cognitive Relationships in Infancy. The Development of Affect. New York 1978: Plenum Press.

Kompan Erzar L.K., Skrita moč družine, Ljubljana 2003: Brat Frančišek in Frančiškanski družinski inštitut.

Kompan Erzar L.K., Ljubezen umije spomin, Ljubljana 2006: Brat Frančišek in Frančiškanski družinski inštitut.

Kompan Erzar L.K., Erzar T., Teorija navezanosti, Celje 2011: Celjska Mohorjeva družba.

Kuhar M, Jeznik K., Effects of group discussion attachment styles and facilitation on the quality of deliberation, "Društvena istraživanja« 27 (2018) 2, pp. 281-303.

Mikulincer M., Shaver P.R., Attachment in adulthood: Structure, dynamics and change, NY 2010: Guilford Press.

Mitchell S., Relational concepts in Psychoanalysis, Harvard 1988: University Press. 
Puhar A., Prvotno besedilo življenja, Studia Humanitatis 2004.

Rothschild B., The body remembers: The psychophysiology of trauma and trauma treatment. New York 2000: WW Norton\&Compani.

Rotschild B., The body remembers casebook: Unifing methods and models in the treatment of trauma and PTSD, New York 2003: W.W. Norton\&Compani.

Rotschild B., Help for the helper: The psychophysiology of compassion fatigue and vicarious trauma, New York 2006: W.W. Norton\&Compani.

Schore A., Affect Disregulation and disorder of the Self, New York Norton 2003: W.W. Norton.

Simonič B., Empathic parenting and child development, »The Person and the Challenges" 5 (2015) 2, pp. 109-121.

Stern D., The interpersonal world of the infant, Camridge 1985: Harvard University press.

Stern D., The present moment in psychotherapy and everyday life, New York 2004: W.W. Norton\&Company.

Van der Kolk B., Treating Trauma Survivors with PTSD, Washington, DC 2002: American Psychiatric Press, Inc.

Xie X., Mulej Bratec S., Schmid G., Meng C., Doll A., Wohlschager A., Finke K., Forstl H., Zimmer C., Pekrun R., Schilbach L., Riedl V., Sorg C., How do you make me feel better? Social cognitive emotion regulation and the default mode network, "Neuroimage« 134 (2016), pp. 270-280. 